\title{
Nesting biology of the Aplomado Falcon (Falco femoralis) at Parque Nacional das Emas, central Brazil
}

\author{
Dárius Pukenis Tubelis ${ }^{1,2}$ \\ Departamento de Biociências, Universidade Federal Rural do Semi-Árido, Campus Mossoró, Mossoró, RN, Brazil. \\ 2 Corresponding author: darius.tubelis@gmail.com
}

Received on 17 July 2019. Accepted on 03 October 2019.

\begin{abstract}
The objective of this study was to investigate aspects of the nesting biology of the Aplomado Falcon, Falco femoralis (Temminck, 1822), at Parque Nacional das Emas, Brazil. Woodland (Campo Cerrado) firebreaks were searched for nests in October 2006 and October 2009 by driving a vehicle along a road adjacent to these fire managed vegetation strips. Most (62\%) of the eight nests found were in canopies of fruiting Pouteria torta trees. Nests were at 2.2-3.8 m above ground. Invariably, clutch size was of three cream eggs and nestlings had a white plumage in the first days of life. For two active nests, adults also defended an additional empty nest located in the surroundings. No evidences of nest destruction or predation were detected. Falco femoralis successfully uses firebreaks for breeding at Parque Nacional das Emas.
\end{abstract}

KEY-WORDS: bird, breeding season, egg, Falconidae, fire, nest, reproduction, savanna.

\section{INTRODUCTION}

The Aplomado Falcon, Falco femoralis Temminck, 1822, is widely distributed through the American continents, where it inhabits numerous habitats, except dense forest and mountain tops (del Hoyo et al. 1994, Stotz et al. 1996, Mata et al. 2006). They are often found in grasslands, savannas and open areas, including landscapes dominated by agriculture (Stotz et al. 1996, Sick 1997, Ferguson-Lees \& Christie 2001). This mid-sized falcon feeds mainly on insects and small vertebrates such as birds, lizards, bats and rodents (del Hoyo et al. 1994, Ferguson-Lees \& Christie 2001, Macías-Duarte et al. 2004). Generally, they are resident but some groups can be migratory, such as those that migrate between the high Andes and coastal Peru and Chile; in regions such as the Cerrado, they are resident (Sick 1997, Ferguson-Lees \& Christie 2001).

Despite its wide distribution and commonness, information on its breeding is scarce for numerous regions. Its reproduction has been studied extensively only in North America, where investigations are concentrated in the Chihuahua region, northern Mexico (e.g., Montoya et al. 1997, Macías-Duarte et al. 2004, Meyer \& Williams 2005, Brown \& Collopy 2008). On the other hand, studies in the Neotropical region are lacking. Timing of breeding varies enormously through its extensive geographic distribution and clutches have between 2 and 4 eggs (del Hoyo et al. 1994, FergusonLees \& Christie 2001).
In Brazil, its nesting has been studied in detail in the Atlantic Forest by Granzinolli et al. (2002) but not in other regions. For example, no study examined its breeding in the Cerrado, where only their feeding ecology (Silveira et al. 1997) and habitat use (e.g., Antas \& Cavalcanti 1988, Tubelis \& Cavalcanti 2001, Pacheco \& Olmos 2010) have been studied. This study aimed to investigate aspects of the nesting biology of $F$. femoralis at Parque Nacional das Emas, central Brazil. Characteristics of their nests, eggs and nestlings, and trees used for nesting were described. Results were discussed in terms of its nesting biology in the Cerrado and other regions.

\section{METHODS}

Observations were made at Parque Nacional das Emas, Goiás state, Brazil. This 132,000 ha conservation unit harbors several vegetation physiognomies typical of the Cerrado ecoregion. Grasslands and savanna woodlands are the major matrix types and usually cover uplands (França et al. 2007). Savanna woodlands (Campo Cerrado and Cerrado sensu stricto) have a dense herbaceous stratum, and numerous shrubs and trees (Eiten 1972 \& 1993). Climate in this region is marked by two well-defined periods: the rainy season occurs between October and April, while the dry season occurs between May and September. Annual precipitation ranges between 1200 and $2000 \mathrm{~mm}$ (Assad 1994) and elevation ranges between 720 and $900 \mathrm{~m}$ a.s.l. (França et al. 2007). 
At Parque Nacional das Emas, park managers usually burn strips of grasslands and savanna woodlands in the dry season almost annually to stop the spreading of fire originated on adjacent farmland. These firebreaks called aceiros by managers and scientists lie between two unsealed roads and are usually $25-100 \mathrm{~m}$ wide (RamosNeto \& Pivello 2000, França et al. 2007). Woodland firebreaks have a grassy stratum dominated by Capim Flecha grass (Tristachya leiostachya Ness), that can be near $200 \mathrm{~cm}$ high when fully developed with reproductive parts. If controlled burnings occur every 1-2 years, Capim Flecha grass keeps $10-30 \mathrm{~cm}$ high at firebreaks (França et al. 2007). Campo Cerrado patches, managed or not by fire, are a major habitat for F. femoralis at this park and in central Cerrado (Silveira et al. 1997, Antas \& Cavalcanti 1988, Tubelis \& Cavalcanti 2001, Pacheco \& Olmos 2010).

Campo Cerrado woodland firebreaks were searched daily for nests in mornings (08:30 to $11: 00 \mathrm{~h}$ ) and afternoons (14:30 to $18: 30 \mathrm{~h}$ ) between 01 and 11 October 2006 and between 05 and 08 October 2009 by driving a vehicle slowly along a road adjacent to them. This search was initiated in early October because active large nests built in trees of firebreaks were found in September 2006, when the park was visited by the author to carry out other ornithological studies. Only firebreaks were sampled due to the facility of their access from adjacent roads. The search covered a total of $32 \mathrm{~km}$ of firebreaks crossing six extensive patches of Campo Cerrado vegetation located in the interior $(n=2 ; 12 \mathrm{~km})$ and at the edge of the park $(n=$ 4; $20 \mathrm{~km}$ ). Campo Cerrado patches not managed by fire were not sampled due to time unavailability, and because firebreaks provide a better visibility than unmanaged patches due to short Capim Flecha grasses.

When a large nest was detected, the observer approached it on foot to identify the bird associated to it. This because the Red-legged Seriema Cariama cristata (Linnaeus, 1766), the Buff-necked Ibis Theristicus caudatus (Boddaert, 1783), the Curl-crested Jay Cyanocorax cristatellus (Temminck, 1823) and raptors also build large nests in tree canopies in Campo Cerrado patches at this park (pers. obs.).

After being examined on the occasion of their findings, nests were visited 2-3 times until 11 October and once between 11 and 14 November 2006. Nests found in 2009 were not re-visited. Nests were visited whenever possible (logistic), thus, visits varied between 1 and 3 (Table 1). During each visit to a nest, eggs and nestlings were counted, but not handled. Nest contents were examined by using a mirror attached to a telescopic pole. The inferior portion of the nests had their height from the ground measured with a Bosch laser tape. A branch of the tree used for nesting was collected to help identification of the plant species. Four tall trees were climbed once to photograph eggs and nestlings.

\section{RESULTS AND DISCUSSION}

Eight nests of F. femoralis were found in Campo Cerrado firebreaks at Parque Nacional das Emas in October 2006 and October 2009 (Table 1). As the observer did not record the precise location of the nests found in 2006, it was not possible to know if falcons used the same trees for nesting in 2009. Further, considering only nests found within a given Campo Cerrado patch, two nests were

Table 1. Content and height of nests of the Aplomado Falcon (Falco femoralis) found in Campo Cerrado firebreaks (strips of savanna woodlands managed by fire) at Parque Nacional das Emas, central Brazilian Cerrado, in 2006 and 2009, with the number of visits to each nest. The sequence of nests follows the first day of inspection.

\begin{tabular}{llcc}
\hline Nest & Nest content & $\begin{array}{c}\text { Height } \\
(\mathbf{m})\end{array}$ & $\begin{array}{c}\text { Number } \\
\text { of visits }\end{array}$ \\
\hline $\mathbf{2 0 0 6}$ & & & 4 \\
1 & Three eggs (02 and 03 Oct); three nestlings (08 Oct); empty nest (13 Nov). & 3.6 & 4 \\
2 & $\begin{array}{l}\text { Three eggs (03 and 07 Oct); Two eggs and one nestling (08 Oct); Three } \\
\text { nestlings (09 Oct); Two young flying with difficulties with adults (12 Nov). }\end{array}$ & 3.4 & 5 \\
& Three eggs (03 Oct); Two nestlings and one egg (07 Oct); Three nestlings (08 & 3.8 & 4 \\
3 & Oct); One young flying with difficulties with adults (13 Nov). & & \\
& Three eggs (04, 05 and 06 Oct); three nestlings (11 Oct). empty (12 Nov). & 2.2 & 5 \\
5 & Three eggs (07, 08 and 10 Oct); Two young flying with difficulties with adults & 2.4 & 4 \\
$\mathbf{2 0 0 9}$ & (12 Nov). & & \\
6 & Three eggs (06 Oct). & 3.6 & 1 \\
7 & Three nestlings (07 Oct). & 4.2 & 1 \\
8 & Three eggs (08 Oct). & 3.1 & 1 \\
\hline
\end{tabular}


distant only $800 \mathrm{~m}$ from each other in 2006 . The other patches had only one nest, in both years. Calculating an overall mean distance for the eight nests would not be adequate, as it would strongly reflect the distribution of the surveyed areas, and not real distances between existing nests. This is because other nests could be located in areas of savanna located between the sampled patches. Six of the eight nests were at less than $70 \mathrm{~m}$ from the park's frontier, while other two were in more interior portions of the park (firebreaks located at $2-8 \mathrm{~km}$ from its frontier). As longer distances were driven at the park's edge than in its interior, these numbers might reflect the sampling effort, and not nest-site selection.

Nests were rough and nearly round structures built with numerous sticks and twigs, a few leaves and clay; contrary to that described by Ferguson-Lees \& Christie (2001), grasses were absent (Fig. 1). They were built in tree canopies, and five $(62.5 \%)$ of them were in fruiting Pouteria torta (Mart.) (Sapotaceae). Trees that supported the other three nests could not be identified due to the loss of branches and photographs, but certainly were not P. torta. The height of nests ranged between $2.2 \mathrm{~m}$ and $3.8 \mathrm{~m}$ above the ground (Table 1 ), with a mean of 3.29 $\mathrm{m}(\mathrm{SD}=0.35)$.

Eggs and nestlings of $F$ femoralis were found in both years (Table 1). Eggs were of cream color and had some darker patches originated from dust (Fig. 1C). Clutches were always of three eggs. Observations permitted to examine hatching only for nests 1, 2, 3 and 4 (Table 1). Based on them, it was known that the 12 eggs originated 12 nestlings. Nestlings were born between 03 and 11 October in 2006 and before 07 October in 2009. Nestlings had a white plumage when aging 1-2 days (Fig. 1D). For two nests, no adults or young were found in the nest or in their surroundings in November 2006. Due to the long interval between visits, it was not possible to know if young had success or not, as predation, infanticide and fledging can be involved in nest success (FergusonLees \& Christie 2001, Brown \& Collopy 2008). On the other hand, reproduction was successful (sensu Brown \& Collopy 2008) for nests 2, 3 and 5, as adults were detected when flying with one or two young in the surroundings of their nests (Table 1).

As incubation by $F$. femoralis lasts for about 30-32 days (del Hoyo et al. 1994, Ferguson-Lees \& Christie 2001) and young were born in early October, egg laying might have occurred in early September or late August. Thus, breeding activities such as pairing, the search for nesting sites and its nest building might start in August, coinciding with the end of the dry season in central Cerrado. October appears to be the main month involving young-care; this activity also reaches the next month, as adults still fly with their young around the nest until at least mid-November. The conduction of
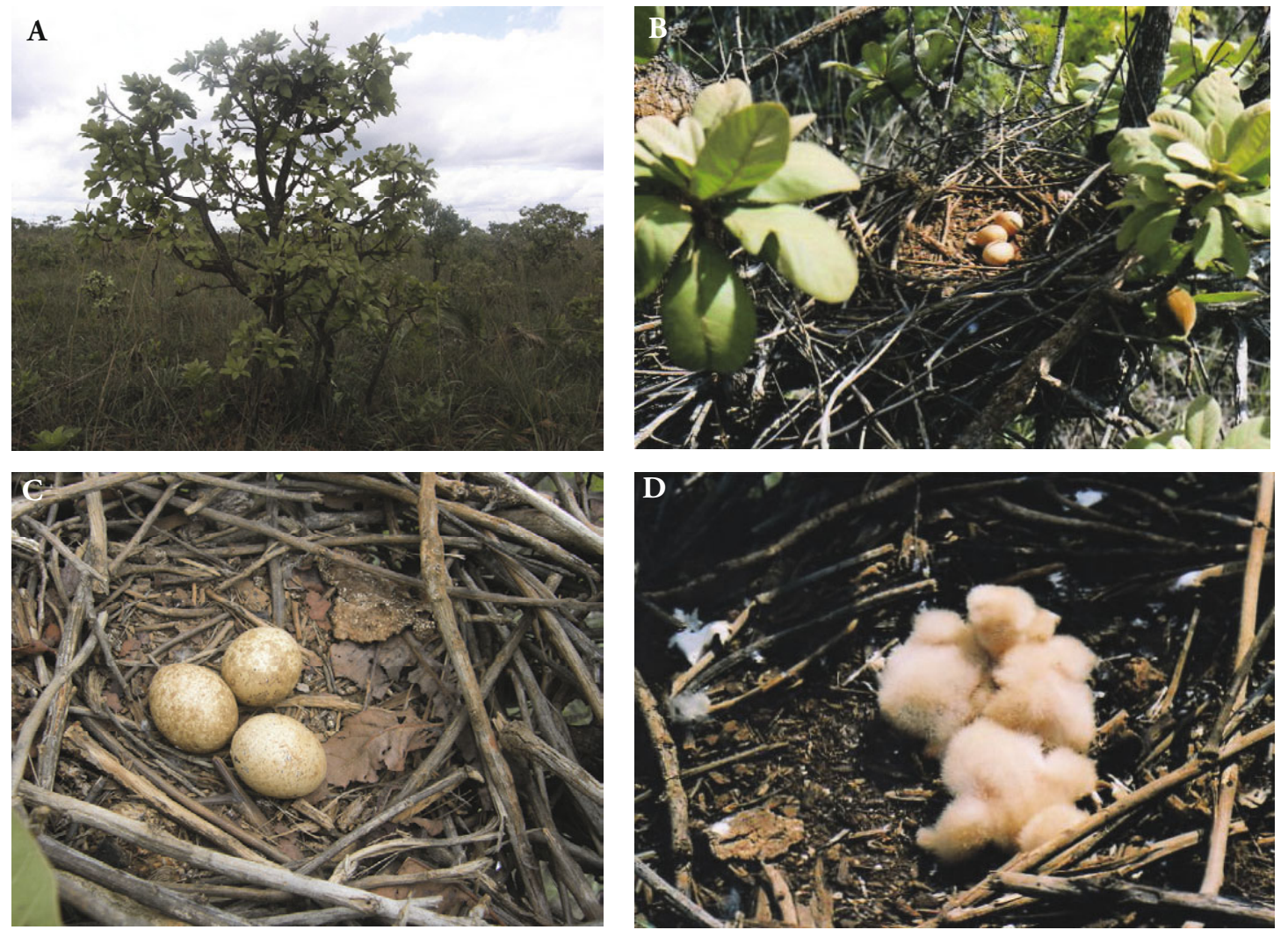

Figure 1. Aspects of the nesting biology of the Aplomado Falcon (Falco femoralis) in Campo Cerrado woodland firebreaks at Parque Nacional das Emas, central Brazilian Cerrado, in October 2006: (A) a nest in a short Pouteria torta tree; (B) detail of a nest built in a fruiting $P$. torta tree; $(\mathbf{C})$ a nest with three eggs; (D) two days old nestlings in a nest. 
observations year-round in future studies will bring more detailed information on the length of different activities of their breeding in central Cerrado.

Generally, when the observer approached the nests in October, the adults left it; then, the pair kept flying around the tree and, alternately, performed a few flights towards the observer, with no physical contact, as often reported for falcons (e.g., del Hoyo et al. 1994, Sick 1997, Ferguson-Lees \& Christie 2001). On the other hand, the adults associated with two nests with eggs or nestlings also performed these defensive flights when the observer approached other nest distant about $15 \mathrm{~m}$ and $20 \mathrm{~m}$ from their nests. These nearby nests were very similar in structure to the active nests, but were empty (had no eggs or nestlings in October 2006). This behavior appears to be an attempt of distraction to make the observers (or potential predators) not find the real active nest.

No evidences of nest destruction or predation were detected in nests during this study. As observations made in October and November 2006 were separated by about 30 days, the absence of a nestling or young in the nests might represent predation, infanticide or a successful fledging prior to the latest inspection. The hatching rate of $100 \%(n=4)$ observed in this study is higher than that recorded in other regions (e.g., Montoya et al. 1997, Macías-Duarte et al. 2004, Meyer \& Williams 2005, Brown \& Collopy 2008). It was not possible to know what happened with eggs or young in the other four nests.

This is the second study to reveal a high percentage of occurrence of nests of Aplomado Falcons in a particular tree species. This is because Montoya et al. (1997) reported a preference for Yucca elata trees in Mexican desert grasslands, considering a sample of seven nests. Other studies have not identified the plant species used for nesting or involved a few nests, not being able to identify a choice (e.g., de Lucca \& Saggese 1996, Granzinolli et al. 2002, Macías-Duarte et al. 2004, Meyer $\&$ Williams 2005). Also, studies that investigated nestsite selection by these falcons examined physical nest-site characteristics, but not the plant species used for nesting (e.g., Brown \& Collopy 2008).

The preference for $P$. torta trees observed at Parque Nacional das Emas is weaker than that (86\%) reported for Yuccas in Mexican grasslands by Montoya et al. (1997). It was not possible to know the reasons of this differential use of $P$. torta trees, especially because there is a high species richness of trees in Campo Cerrado firebreaks. Differently from that occurred with Yucca trees in Mexican grasslands (Montoya et al. 1997), where they were the only woody plants taller than $2 \mathrm{~m}$, numerous plants were taller than P. torta at firebreaks. However, a similarity between them occurs - Y. elata is the second most abundant plant species in the desert grasslands (Montoya et al. 1997), while $P$. torta is abundant in the studied firebreaks (pers. obs.). In both regions, nest height was higher than $2 \mathrm{~m}$. However, the mean height of nests found at firebreaks is lower than that reported for other regions, such as Argentina (de Lucca \& Saggese 1996) and the Brazilian Atlantic Forest (Granzinolli et al. 2002).

Factors related to the access of adults to the nest, their departure from it, vigilance and avoidance of predators might be involved in the choice of trees for nesting. Interestingly, T. caudatus (pers. obs.) and $C$. cristata (Tubelis 2019) also use $P$. torta trees for nesting at firebreaks in October-November at Parque Nacional das Emas. This later study showed that $C$. cristata also built most $(69 \%)$ of their nests in $P$. torta trees. As Aplomado Falcons sometimes use abandoned nests of other birds (del Hoyo et al. 1994, Ferguson-Lees \& Christie 2001), further observations are necessary to know if these falcons use abandoned nests of seriemas, ibises and other bird species in the Cerrado.

The finding of clutches of 3 eggs in woodland firebreaks agrees with results of major compilations of information on the breeding biology of $F$. femoralis, that reported nests with 2-4 eggs (del Hoyo et al. 1994, de Lucca \& Saggese 1996, Ferguson-Lees \& Christie 2001). Similar to this study, several studies had reported as frequent clutches of 3 eggs in a diverse range of regions (e.g., Newton 1977, del Hoyo et al. 1994, Montoya et al. 1997, Granzinolli et al. 2002).

This is the third study to examine the use of firebreaks as nesting sites by birds at Parque Nacional das Emas, as it has been shown that Burrowing Owls [Athene cunicularia (Molina, 1782)] and Red-legged Seriemas build their nests in fire managed grasslands and savanna woodlands, respectively (Tubelis \& Delitti 2010; Tubelis 2019). In both cases, nests were more abundant at firebreaks than in unmanaged vegetation, and it was argued that a major reason leading to this nest choice was the shortening of tall Capim Flecha grasses by frequent burning. Apparently, the burning of firebreaks in June-July (França et al. 2002) is also leading to suitable conditions for the breeding of F. femoralis. Likely, a short grassy stratum favors vigilance and prey capture by falcons at firebreaks. As unmanaged woodlands were not investigated in this study, further research is necessary to understand the influence of fire management on the breeding biology of this species in the Cerrado. This study has shown that Aplomado Falcons can successfully reproduce in Campo Cerrado firebreaks at Parque Nacional das Emas.

\section{ACKNOWLEDGEMENTS}

The Universidade Federal Rural do Semi-Árido (UFERSA) provided logistic support. Rogério Souza (IBAMA) provided a license to study birds at Parque Nacional 
das Emas. Mário Barroso Ramos-Neto provided a map of this park. Margarete Naomi Sato identified the plant species. Cristiano S. Azevedo and João Paulo S.V. de Alencar improved this manuscript by making numerous suggestions. This research was funded by Fundação de Amparo à Pesquisa do Estado de São Paulo/FAPESP (Process No. 05/00773-3) and Conselho Nacional de Desenvolvimento Científico e Tecnológico/CNPq (Process No. 471360/2006-6).

\section{REFERENCES}

Antas P.T.Z. \& Cavalcanti R.B. 1988. Aves comuns do Planalto Central. Brasília: Universidade de Brasília.

Assad E.D. 1994. Chuva nos cerrados: análise e espacialização. Brasília: EMBRAPA/SPI.

Brown J.L. \& Collopy M.W. 2008. Nest-site characteristics affect daily nest-survival rates of Northern Aplomado Falcons (Falco femoralis septentrionalis). Auk 125: 105-112.

de Lucca E.R. \& Saggese M.D. 1996. Nidificación del Halcón Aplomado (Falco f. femoralis) en la provincia de San Luis. Hornero 14: 77-80.

del Hoyo J., Elliot A. \& Sargatal J. 1994. Handbook of the birds of the world (New World Vultures to Guineafowl), v. 2. Barcelona: Lynx Editions.

Eiten G. 1972. The Cerrado vegetation of Brazil. Botanical Review 38: 205-341.

Eiten G. 1993. Vegetação do Cerrado, p. 17-73. In: Pinto M.N. (ed.). Cerrado: caracterização, ocupação e perspectivas. Brasília: Universidade de Brasília.

Ferguson-Lees J. \& Christie D.A. 2001. Raptors of the world. Boston: Houghton Mifflin Company.

França H., Ramos-Neto M.B. \& Setzer A. 2007. O fogo no Parque Nacional das Emas. Brasília: Ministério do Meio Ambiente.

Granzinolli M.M., Rios C.H.V., Meireles L.D. \& Monteiro A.R. 2002. Reprodução do Falcão-de-coleira Falco femoralis Temminck 1822 (Falconiformes: Falconidae) no município de Juiz de Fora, sudeste do Brasil. Biota Neotropica 2: bn01902022002.

Macías-Duarte A., Montoya A.B., Hunt W.G., Terrazas A.L. \& Tafanelli R. 2004. Reproduction, prey and habitat of the Aplomado Falcon (Falco femoralis) in desert grasslands of Chihuahua, Mexico. Auk 121: 1081-1093.

Mata J.R.R., Erize F. \& Rumboll M. 2006. A field guide to the birds of South America. London: Harpercollins Publishers Ltd.

Meyer R.A. \& Williams S.O. 2005. Recent nesting and current status of Aplomado Falcon (Falco femoralis) in New Mexico. North American Birds 2: 352-356.

Montoya A.B., Zwank P.J. \& Cardenas M. 1997. Breeding biology of Aplomado Falcons in desert grasslands of Chihuahua, Mexico. Journal of Field Ornithology 68: 135-143.

Newton I. 1977. Breeding strategies in birds of prey. Living Bird 16: 51-82.

Pacheco J.F. \& Olmos F. 2010. As aves do Tocantins, Brasil: Jalapão. Revista Brasileira de Ornitologia 18: 1-18.

Ramos-Neto M.B. \& Pivello V.R. 2000. Lightning fires in a Brazilian savanna national park: rethinking management strategies. Environmental Management 26: 675-684.

Sick H. 1997. Ornitologia brasileira. Rio de Janeiro: Editora Nova Fronteira.

Silveira L., Jácomo A.T.A., Rodrigues F.H.G. \& Crawshaw-Júnior. 1997. Hunting association between the Aplomado Falcon (Falco femoralis) and the Maned Wolf (Chrysocyon brachyurus) in Emas National Park, central Brazil. Condor 99: 201-202.

Stotz D.F., Fitzpatrick J.W., Parker-III T.P. \& Moskovits D.K. 1996. Neotropical birds: ecology and conservation. Chicago: University of Chicago Press.

Tubelis D.P. 2019. Fire management and the nesting biology of the Red-legged Seriema (Cariama cristata) in woodlands at Parque Nacional das Emas, central Cerrado. Revista Brasileira de Ornitologia 27:230-237.

Tubelis D.P. \& Cavalcanti R.B. 2001. Community similarity and abundance of bird species in open habitats of a central Brazilian Cerrado. Ornitología Neotropical 12: 57-73.

Tubelis D.P. \& Delitti W.B.C. 2010. Fire management and the nesting of Athene cunicularia (Aves, Strigidae) in grasslands in central Cerrado, Brazil. Biota Neotropica 10: bn02910022010.

Associate Editor: Cristiano S. Azevedo. 